\title{
Framing Scrappage in Germany and the UK; from climate discourse to recession talk?
}

Rachel Aldred and Daniela Tepe

6,626 words

\begin{abstract}
This paper highlights the distinctive discursive framing of transport policy in Germany and the UK. Using an analysis of the introduction of the 'scrappage bonus' in both countries, against the background of the financial crisis, we show how distinct nationally specific discourses and political cultures are expressed within these. The German government was an early adopter of the policy, but the UK government was relatively late in introducing its own scheme. While the German scrappage scheme was introduced officially as an environmental bonus, the UK scheme did not make any reference to environmental concerns. We argue that these differences are important in the context of a wider research aim, to identify nationally specific mobility regimes and to develop an understanding of different possible pathways towards more environmentally friendly transport futures.
\end{abstract}

\section{Keywords}

Europe; scrappage; environment; cars; UK; Germany

THIS IS A PRE-PRINT - the final version may be found at http://www.sciencedirect.com/science/article/pii/S0966692311001293 


\section{Framing Scrappage}

\section{Introduction}

The paper analyses the framing of European car scrappage schemes, focusing upon Germany and the UK. We use scrappage to provide insight into broader problems with transport policy development, to demonstrate the utility of our mobility regimes framework and to indicate directions for future research.

We concur with NGO (Non Governmental Organisation) Transport and Environment (2009) that scrappage schemes, particularly their German and British variants, are problematic. While they may contribute to a reduction in headline $\mathrm{CO}_{2}$ emissions figures for new cars (IHS Global Insight 2010), scrappage schemes have been criticised as an expensive way of achieving relatively small emissions cuts (Monbiot 2009). Taking into account whole-life emissions and changes in consumer behaviour, scrappage may be counterproductive in $\mathrm{CO}_{2}$ terms (Kagawa et al 2011). Scrappage schemes further seem to counteract long-term policy goals around modal shift, as they incentivise the purchase of cars rather than the use of more environmentally friendly transport modes.

Given this, how and why were such schemes put in place, when their value is so questionable (in environmental, social, and even economic terms)? Why were climate change discourses apparently immobilised? And how did the construction of scrappage bring into play national cultural, economic, and political specificities?

In addressing these questions we outline the environmental impasse into which transport policy has fallen at national and European levels. We explain our analytical framework; our concept of mobility regimes and the policy frames approach we use within this. Next we analyse how changes in environmental discourses have affected transport, specifically the shift from a broader 'transport and the environment' discourse to a narrower focus on climate change. Then we discuss our case study, scrappage policy at European, UK, and German levels, with a focus both on national specificity and a broader European shift towards 'recession talk'. Finally we conclude with some thoughts on how our approach could be developed.

\section{Context: transport's environmental impasse}

Hall (2010: 9) identifies climate change as the critical over-arching issue for transport research agendas. Yet the story of transport and $\mathrm{CO}_{2}$ emissions is one of continuing policy failure. The slow rise in car energy efficiency is outweighed by rising car ownership and rising travel distances (Stead 2007). Growing energy demand in the transport sector means that ' [b]y 2030, it is estimated that $33 \%$ of all energy consumed in Europe will be consumed by transport' (Stead 2007:343). This trend is due to longer travel distances (for freight and passengers), more vehicles and increasing air travel.

The policy problem is clear but changes are in the wrong direction. We believe that focusing on culturally specific discourses and political settings can contribute to understanding this impasse. '[A]pparently successful efforts in the transformation of policy rhetoric may fail to transform policy practices because either the rhetoric does not reach the routines of practice or the changes leave contradictory deeper cultural assumptions in place.' (Healey 1999:28). Arguably this happened in UK transport policy as 'new realism' became 'pragmatic multimodalism' (Walton and Shaw 2003). At a 
European level transport policy discourse demonstrates long-standing, acute and unresolved tensions between ideals of European free trade and Europe as a 'global environmental leader' (Hall 2010).

Speaking at the British Sociological Association Presidential Event 2010, John Urry argued that more positive imaginaries and incentives for sustainable futures could help to address this deadlock (Urry 2010). We suggest in this article how a mobility regimes approach can support this project, through developing knowledge about the different political opportunities for change presented in different national policy contexts. What might be considered a 'positive' policy discourse or proposal in Britain might not have the same implications in Germany, and vice versa. Scrappage enables us to study relationships between discourses and policies in contrasting national contexts.

\section{Analytical approach: mobility regimes and policy frames}

We use the term 'mobility regimes' to characterise changing and differentiated structural and discursive factors that shape and constrain ways of moving people and things. Mobility regimes incorporate policy frames, socio-economic specificities, and historically conditioned discourses and practices. The concept implies a research agenda investigating the roles of historically specific economic, political and cultural processes within contemporary capitalist societies (Urry 2000, 2004). It encourages a comparative and socially rooted approach to analysing transport that is multi-levelled and rooted in the history of geographically differentiated transitions to mass motorisation.

Our approach acknowledges the relative autonomy of transport while maintaining its connection to other areas of policy and practice. Mobility regimes are affected by environmental discourses and associated policy-making, which have now achieved some legitimacy within transport policy processes (Golbuff and Aldred 2011). Mobility regimes are embedded in, and operate through, everyday routines including work (do employers allow home working?) and schooling (does locality or 'choice' dominate school provision?). The approach allows a focus upon the changing and contextual nature of the 'car system' (Urry 2007; Dennis and Urry 2009). Mobility regimes shape political responses to problems caused by twentieth century transitions to mass motorisation and so produce both obstacles to change and entry points.

Because of its multi-levelled nature a mobility regimes approach can co-exist with a variety of methodological approaches. Here we use policy frames to analyse scrappage policies. Concepts of framing were initially used in the sociology of social movements and in political science to analyse how the definition of political and sociological issues affects agenda setting. For social movements to succeed exponents must reformulate their values and motivations, adapting them to the orientations of those they wish to organise (Snow et al. 1986; Tarrow 1994; Della Porta and Diana 1999).

In political science, two distinct perspectives on framing draw on different bodies of social scientific literature and have each developed a distinct research focus (Daviter 2007: 656). The first perspective builds upon Schattschneider's (1960) understanding of politics where conflict and competition structure 'the terms of reference and the development and processing of political ideas and political demands' (Mair 1997: 949). This implies a focus upon political actors, their interests and interest constellations. The second perspective draws on the work of Schön and Rein (1994). Framing here 
'offers a useful metaphor for how actors give a coherent organisation to a complex reality by selecting for attention a few salient features. At the same time, they argue also that the nature of 'objective' reality might be found in the world's tendency to resist our interpretations, leading to a discovery of the limitations of particular frames' (Dudley 1999: 51).

A policy frames approach has contributed to the analysis of climate change discourse, focusing on competing interest claims and the use of metaphors or symbols to personify climate change and potential victims (e.g. Slocum 2004a on polar bears, Fletcher 2009 on the redefinition of climate change as a 'security' issue). The (re)definition of climate change raises questions about the scale of political action. Climate change is seen as exemplifying a shift towards the global level, a transnational problem transcending state boundaries. Yet nationally specific approaches still contribute to the framing of policies at different levels (Jordan 2002; Hajer 1995; Knill and Lenschow 1998; Lowe and Ward 1998; Brand 2007).

A politics of scale and levels does not mean that the national has become obsolete but encourages us to focus on the redefinition of scales of political action. Bulkeley argues (2005: 890) that as scales of engagement shift, objects of governance are themselves transformed. A shift from European to national level policy-making, in line with the principle of subsidiarity, affects the construction of policy objects and discourses. In this case the re-nationalisation of automobile policy-making has opened the way to lobbying that seeks to foreground the 'national car industry' as imagined community - and as victim rather than villain. The use of different scales to shape policy discourse produces social and environmental 'realities' that in turn shape political values and spatial politics (Bunce and Desfor 2007).

Environmental issues are framed in different ways, using concepts such as 'environmental justice'. Such concepts are not fixed but form, in Aygeman and Evans' phrase 'vocabularies of political opportunity' (quoted in Walker, 2009: 370). Different vocabularies have different political implications, as many people particularly in lower income groups find it hard to relate to 'the environment' (Burningham and Thrush 2004), and climate change perceived as a global rather than a local issue may compound this problem. Yet while climate change is usually narrated as 'global' it can be 'scaled' at different levels in opposition to this dominant discourse through city-level campaigns and programmes (Bulkeley 2005, Mulugetta et al 2010).

Scrappage policy-making similarly mobilises and marginalises competing vocabularies of political opportunity, both 'environmental' and 'economic'. Scrappage may not even be seen as a 'transport policy'; being constructed within the frame of business and enterprise policy, or environmental policy more widely, as we discuss below. However this is characteristic of transport policy, which incorporates and is incorporated within many other policy domains such as health (Aldred 2010).

Focusing on scrappage as a transport policy here helps us to understand how issues relating to climate change and economic concerns are played off against each other in different policy contexts. Below we examine the changing policy consensus leading to the rapid spread of scrappage policies across European countries, focusing upon differences between Germany and the UK. We attribute these differences to distinct mobility regimes shaping the policy frames used to understand the interrelation between 'transport' and 'climate change'. We aim to give an insight into the 
distinctiveness of historically specific national mobility regimes, encouraging further research in the area.

\section{From environmental discourse to climate change discourse}

European transport policy discourse has increasingly been shaped by language and concepts used in climate change discourse (Hall 2010, Walton and Shaw 2003). The European car industry has been targeted by such challenges and has made concessions, accepting previously opposed mandatory $\mathrm{CO}_{2}$ emissions regulation in 2008. The conceptualisation of climate change as a super-issue superseding other environmental issues framed the definition of policy issues and the scope of appropriate responses, in culturally specific ways. This has affected transport policy-making at European and national levels, with somewhat different effects in Germany and in the UK.

In the case of cars and $\mathrm{CO}_{2}$ legislation, the perceived urgency of the climate threat ultimately trumped the automobile industry's long opposition to mandatory regulations. Despite limitations, the legislation both used climate change discourse to frame transport policy-making and represented a challenge to core beliefs traditionally expressed in European transport policy documents (Giorgi and Schmidt 2002). The policy debate was constructed within an 'ecological modernisation' perspective (Hajer 1995) stressing commonalities between economic and environmental interests. This allowed the legislation to appear as serving otherwise potentially opposing interests in the wider context of apparently healthy and growing economies. With $\mathrm{CO}_{2}$ the main target, issues less obviously amenable to technological solutions (such as road danger, local congestion and local air pollution) were sidelined.

The proposed emissions legislation was portrayed as incentivising technological improvements to support environment and economy, tweaking a fundamentally healthy European automobile market and helping industry to plan more effectively for a lowercarbon future. Importantly, attempts to limit speeds and advertising were removed from draft legislation, demonstrating the effective lobbying capability of the automobile industry at European as well as at national levels. Potential solutions became based around reducing engine emissions while keeping other factors constant, allowing the 'car system' to continue expanding on a structural level, while slowly decarbonising in terms of individual new cars. Moreover, the assumption that emissions regulation should support the automobile industry left 'environmental transport policy' vulnerable to a shift in policy frame if economic conditions changed.

At national levels, the impact of climate change discourse has been substantial but differentiated. This is demonstrated by a comparison of policy debates in the UK and Germany. Other environmental discourses have continued to have a higher priority in German political discourse, while in the UK there has been a more dramatic shift at least at an official level. There is a history in the UK as defining transport as an environmental problem, in terms of local pollution, local congestion, and quality of life. Prior to the institutionalisation of climate change discourse, in the 2001 UK environmental attitudes and behaviour survey (DEFRA 2001) most respondents spontaneously mentioned 'traffic' as the key environmental issue for the future.

The terms of the UK debate have shifted dramatically since then as 'cars and $\mathrm{CO}_{2}$ ' has become increasingly prioritised. This was demonstrated through the setting up and resourcing of bodies such as the Low Carbon Vehicle Partnership (LCVP) and the Office for Low Emission Vehicles (OLEV). This looks set to continue with the current 
Conservative-Liberal Democrat government focusing even more strongly on technological solutions to environmental problems (Hammond 2010). While the less technologically focused Cycling England and Commission for Integrated Transport were axed in the new government's quango ${ }^{1}$ review, LCVP (an ad hoc advisory group) and OLEV (a cross-Whitehall team) were left out of this review and continue to exist.

In Germany, awareness of global warming is high: more than half of the population fear it will strongly affect themselves, their quality of life and their families (Weidner 2005: 56). However, it is seen as among a number of environmental problems: surveys rank climate change as the third most pressing environmental problem, behind protecting water, soil and air and conserving energy sources and raw materials (Kasemir et al. 2000). According to Weidner the normative concept of 'public interest' plays a distinctive role in German politics and policy-making, 'especially when justice and equity issues are involved' (Weidner 2005: 75). This concept is strongly related to a national public interest, contrasting with a global or cosmopolitan norm of justice.

Although climate change discourse has increasingly influenced German political discourse, a politics of more localised transport pollution continues to mobilise citizens. Germany retains strong traditions of locally regulating car emissions (in particular, particulate matter) through city-level action. In response to the car scrappage scheme a number of German cities introduced local 'bike scrappage' programmes (Transport and Environment 2009a). By contrast in Britain a local politics of vehicle emissions has been relatively lacking until the recent London Low Emission Zone, and $\mathrm{CO}_{2}$ has become the key campaigning issue in the area of transport.

As the ' $\mathrm{CO}_{2}$ and cars' discourse has become more prominent, especially at European and UK levels, this has generated both opportunities and problems. On one hand ' $\mathrm{CO}_{2}$ and cars' discourse has helped to give 'the environment' a higher priority due to the high profile of climate change as global threat. However, the danger is that climate change appears as an issue which (a) cannot be understood by people through everyday experiences and (b) appears amenable to technical fixes - in this case, lower carbon cars (Slocum 2004).

\section{The Year of Scrappage}

The compromise cars and $\mathrm{CO}_{2}$ regulations crawled into place at the end of 2008 . 2009 became the year of scrappage or 'cash for clunkers' ${ }^{2}$; although as we explain below different socio-political contexts in Britain and Germany shaped the two countries' 'year of scrappage' differently. As Europe moved deeper into recession, people were buying smaller cars, stopping buying cars, or driving less. In the UK in 2008, motor traffic fell by $1 \%$, unprecedented in recent decades (Webster 2009). Such a reduction is a policy aim in many European countries, including UK and Germany (e.g. Department for Transport, 2009). However, instead of hailing a success, the debate was abruptly reframed from environmental opportunity to economic threat. As the focus shifted from

\footnotetext{
${ }^{1}$ Quango: Quasi-Autonomous Non-Governmental Organisation, otherwise known as NonDepartmental Public Bodies.

${ }^{2}$ The term refers to the introduction of the US version of scrappage (US Car Allowance Rebate Scheme) which only allowed the exchange if the new car is smaller than the car to be scrapped and uses less petrol (NY Times 2009). The US scheme involved detailed instructions on the scrappage process in an attempt to avoid reselling.
} 
'European environmental policy' to 'national car industries', the potential for negative economic events to generate positive behaviour change became inconvenient.

This was a two-fold shift in policy frames: firstly, framing stagnating car sales and falling travel as a crisis and secondly, framing this crisis as one appropriate for action at the national level. This produced a discursive context for European countries to protect their 'own' industry. States hurriedly introduced national scrappage schemes, paying drivers to have old cars destroyed conditional on buying a new one. The details of these schemes were nationally decided, but exhibited similar characteristics: although some included limited environmental criteria, none gave drivers money to scrap an old car in exchange for a public transport season ticket, a bicycle or walking equipment.

Figure 1 demonstrates how European scrappage schemes 'revitalised' the European car market, whose sales fell only by $1.6 \%$ in 2009 , despite the recession (Motor Trade Index 2010). In Italy, France and Spain scrappage schemes boosted car sales as late as January 2010; according to the French Car Makers Association, French car sales rose by 14\% in January 2010 (Global Times 2010).

Figure 1: New passenger car registrations, Germany, UK, EU15

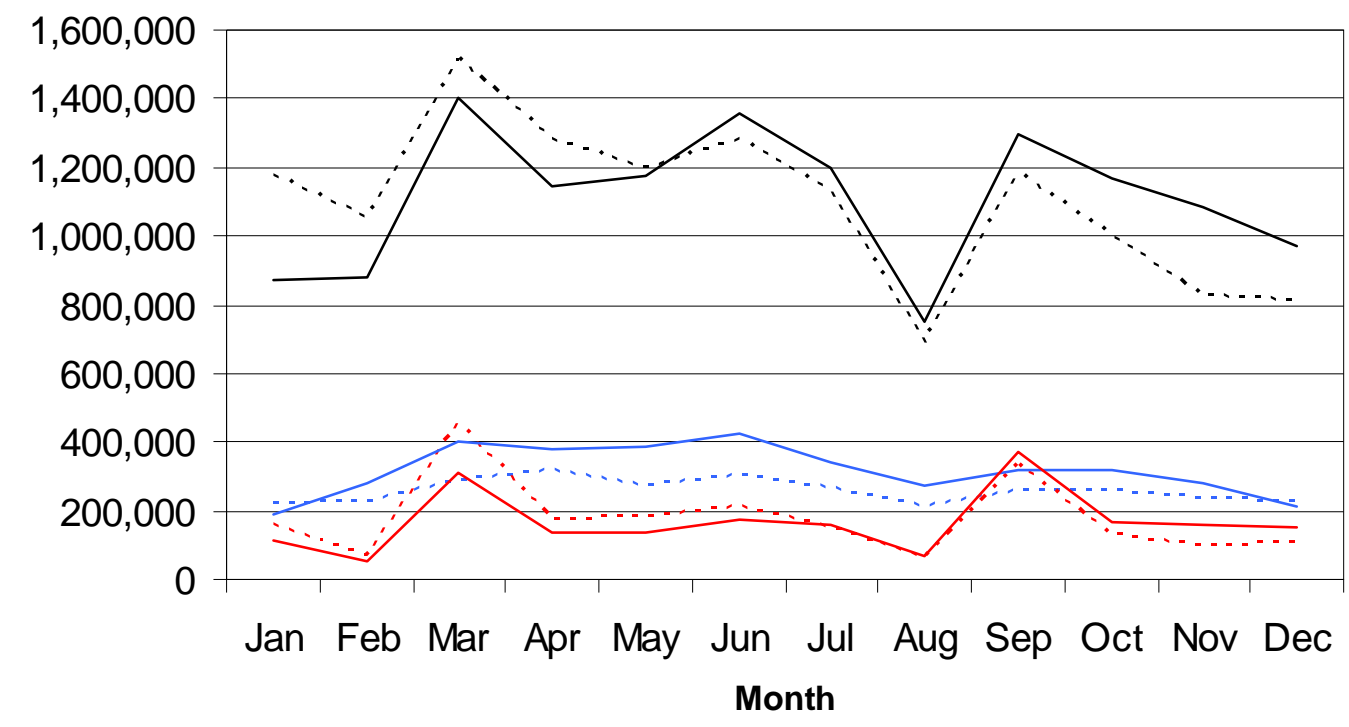

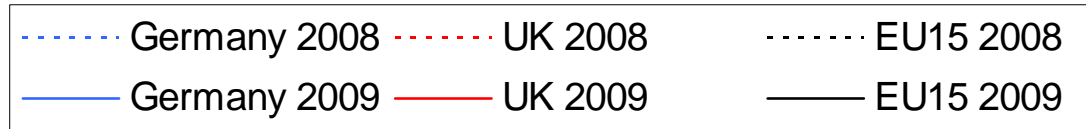

Source: ACEA data ${ }^{3}$

While national schemes are distinct, with Spain offering interest free loans and Austrian car dealers paying $50 \%$ of incentives, the only western European countries that had not introduced scrappage schemes of any couleur by late 2009 were the

\footnotetext{
${ }^{3}$ http://www.acea.be/index.php/news/news_detail/new_vehicle_registrations_by_country/
} 
Scandinavian countries, Belgium and Switzerland. Figure 2 shows the main features of the major European scrappage schemes.

Figure 2: Key features of major European scrappage schemes

\begin{tabular}{|c|c|c|c|}
\hline Country & $\begin{array}{l}\text { Age of car to be } \\
\text { scrapped }\end{array}$ & Emissions criteria $^{4}$ & Incentive \\
\hline France & $>10$ years & $<160 \mathrm{~g} / \mathrm{km}$ & $€ 1-2000$ \\
\hline Italy & $>10$ years & $\begin{array}{l}<140 \mathrm{~g} / \mathrm{km} \text { (petrol) } \\
\text { or }<130 \mathrm{~g} / \mathrm{km} \\
\text { (diesel) }\end{array}$ & $€ 1500$ \\
\hline Spain & $>10$ years & $<140 \mathrm{~g} / \mathrm{km}$ & $\begin{array}{l}\text { 0\% loan (up to } \\
€ 10000)\end{array}$ \\
\hline Germany & $>9$ years & None & $€ 2500$ \\
\hline UK & $>9$ years & None & $\begin{array}{l}£ 2000 \text { (split } \\
\text { between dealer } \\
\text { and government) }\end{array}$ \\
\hline
\end{tabular}

In September 2008 the German 'Abwrackprämie' was proposed by Mathias Wissmann, President of the VDA (Verband Der Automobilindustrie, automobile industry association) to address the consequences of the financial crises for the German car industry. It was initially promoted by leading SPD (Sozialdemokratische Partei Deutschlands, social democrats) politicians including Minister of Foreign Affairs and shadow chancellor Frank-Walter Steinmeier against voices from the CDU (Christlich Demokratische Union, conservatives) government (Der Spiegel 2009a). Officially introduced as the 'environmental bonus' (Umweltprämie) it introduced in January 2009 as part of the Government's Konjunkturpaket II. The German government put aside 5 Billion Euro to finance the costs of the scheme. Until the scheme ran out in September 2009, 2500 Euro was paid to those qualifying for the bonus.

Britain's scheme was similar except the amount offered to purchasers was more generous and the cost split between the dealer and the government. But the story of its introduction is different. When the UK announced its scrappage scheme in April 2009, ten other European countries already had schemes in place ${ }^{5}$. The British scheme was introduced after a vocal campaign by newspapers and industry lobbyists. In March 2009, the Sun tabloid (Britain's top selling newspaper) launched a high profile campaign to make the UK government 'pay for your bangers' (Lanning 2009). Normally Eurosceptic to the point of xenophobia, the Sun called on the UK government to emulate the Germans. Other newspapers supported the call and on 22nd April the UK scrappage

\footnotetext{
${ }^{4}$ Not including the EURO-IV-Norm

${ }^{5}$ Germany introduced its scrappage scheme in January 2009, with France having introduced its scheme in December 2008. Countries that followed throughout 2009 included Italy, Spain, Portugal, Austria, the Netherlands, UK, Romania, Egypt, Spain, Japan and the US. Russia introduced a similar scheme in 2010 (Russland Aktuell 2009).
} 
scheme was announced. Below we argue that the different policy trajectories in the two countries reflects the relative power positions of the German and the British car industries, and highlights the embeddings of these schemes in nationally-specific discursive structures and policy.

\section{Framing scrappage in Germany and the UK}

Although the UK and Germany both introduced scrappage in apparently similar political contexts, the introduction of the schemes highlights historically specific societal discourses and political cultures reflected in the 'framing' of the topic. This section analyses how the strength of the car industry and environmental policy discourses interacted to produce different constructions of 'scrappage' in Germany and the UK. In Germany both are strong while in the UK both are relatively weak; this matters in the framing of scrappage policy and challenges to it.

Although the full impact of the economic crisis is yet to be seen, the German car industry remains economically and politically powerful. This is despite leading social scientists repeatedly announcing its death (Deutschlandradio 2007) as in 2004 when Opel laid off a significant part of its workforce ${ }^{6}$. Like the French car industry, the German industry has maintained its competitive position in relation to Japanese companies Toyota and Honda'. Pries (2005:2) argues that this was due to the state playing 'a significant, also steering role in the economy, specifically in the motor economy'. The 'old' European model of 'Sozialpartnerschaft' (social partnership) dominating the regulation of various societal interests in Germany was decisive.

The German car industry even increased its dominance in German society and politics because of its internationally competitive position, with new records in exports during the early 2000s and increasing employment in the sector (Nunnenkamp 2008; see also 1998). Its influential role inside and outside Germany is further strengthened by its organisational structures. The Verband deutscher Automobilindustrie (VDA) unites not only all car manufacturers but also most component suppliers.

The British car industry in comparison has been consistently weakened since the 1960s, finding it increasingly difficult to secure an internationally competitive position (Church 1994). This was aggravated by Thatcherite attempts to shift the British economy away from regionally based manufacturing both unions and the Labour Party were traditionally strong. During this period once dominant British-owned mass-market manufacturers collapsed or were bought up. The remaining UK-based car industry is now export-oriented, with around 200,000 workers directly accounting for $5.9 \%$ of UK manufacturing employment (NAIGT 2009). While production remains significant, employment levels continue to fall. UK car manufacturing has shed over 10,000 employees on average every year for the last 10 years (NAIGT 2009).

While postwar UK economic development - increasing favouring London-based and financial interests - has weakened the position of regions relying on manufacturing, the situation in Germany is different. The regionalisation of the German car industry strengthens the hand of German federal states (Laender) in key locations such as North Rhine Westphalia and Bavaria. Regional politicians there promote the regionally based

\footnotetext{
${ }^{6}$ The impact of the refusal of General Motors in late 2009 to sell Opel have yet to be seen.

7 The full impact of Toyota's crisis of mass car recalls is not yet known.
} 
motor industry when it comes to securing locations and/or questions of employment. The different political situation in the two countries highlights the different construction of 'scales of engagement in policy' (Bulkeley 2005). One example of the role of German regional politicians is former Hessian minister, Roland Koch's efforts in negotiating a buyer of Opel in 2009 (Der Spiegel 2009). Partly due to the absence of federal states, partly due to the weakness of the UK car industry in linking interests with political regions, there is no UK equivalent.

The culture of the manufacturers matters as well as their contrasting economic positions. In Germany, manufacturers tend to make middle market and high end vehicles, rather than the smaller vehicles made in France or Spain. While this is part of the regional organisation of European car production, it simultaneously maintains different national political cultures. For German manufacturers, promoting their product as 'green' is a marketing strategy aimed at more affluent customers. A message that scrappage is economically necessary would potentially damage their brands, which seek to position themselves as luxury or successful, not struggling. ${ }^{8}$ In the UK, where the car industry has long been seen as struggling, economic messaging may be more important and less threatening to the brands.

Calling the scheme an environmental bonus (while it was publically discussed as a scrappage-bonus) reflects the self-representation of the German Government as Green, and the media representation of Angela Merkel as the 'Klimakanzlerin' (climate chancellor) (Frankfurter Rundschau 2009). It may also be an attempt to connect with the self-representation of Germans as 'green drivers' (see European Commission 2007). 'Eco-driving' has been included in the German driving test since the end of the 1990s (see http://www.neues-fahren.de/neues-fahren/default.htm). As Meyer et al. 2002 show, the integration of environmental discourses plays an important role in German politics. Policy initiatives may be portrayed and even labelled environmentally friendly, even if challenging discourses are supported by leading environmental organisations.

Major German environmental NGOs opposed the 'environmental' bonus as did the Bundestag parties Die Grünen and Die Linke. ${ }^{9}$ Criticisms related to the lack of environmental conditions for the new car purchased, which might have included limits on the car's $\mathrm{CO}_{2}$ emissions or petrol consumption per kilometre (Der Spiegel 2009). Other criticisms questioned the effectiveness of the scheme in terms of supporting German car manufacturers, the effectiveness of the scheme in actually scrapping old cars (NY Times 2009a) and the scheme's long-term consequences.

In the UK, by contrast, a strikingly similar scrappage scheme was never portrayed as 'environmental', demonstrating that environmental discourse is less important to the framing of transport policy-making. Scrappage was introduced relatively late and the UK government initially 'only' allocated $£ 300$ million to the scheme (BBC News 2009). While the UK's motor industry body - the Society of Motor Manufacturers and Traders (SMMT) - had lobbied for the scheme, the European Commission coordinated pressure from other European leaders (Independent 2009). In the UK press, discussion of a scrappage scheme only took off after other countries had already introduced such schemes. This we feel is related to the relatively weaker position of the

\footnotetext{
${ }^{8}$ We would like to thank an anonymous referee for this point.

${ }^{9}$ The Greens and the Left Party.
} 
UK motor industry. In this context it is worth noting that the SMMT does not organise only UK-based manufacturers but also manufacturers who sell into the UK.

Following the introduction of the UK scheme, rising vehicle purchases were widely greeted as an economic 'good news story', with relatively little debate around potential environmental consequences. The shift away from car travel encouraged by falling incomes and rising oil prices had been portrayed in the UK media, by governments, and by company and union leaders as a crisis without mitigating features (e.g. Ruddick and Sibun 2009; Clark 2009), rather than - for example - as representing 'good' transport choices by individuals in an unfavourable situation. Scrappage was largely discussed in terms of impact on the car industry, with the most prominent critiques based around nationalism or consumerism (e.g. the likelihood that new cars would be produced abroad, or the failure of dealers to pass on savings to the consumer), rather than around the environmental impact of the scheme.

In the UK, the prioritisation of the economic over the environmental and failure to consider how ecological modernisation (Mol 2001) might connect the two demonstrates the relative failure to embed an environmental transport discourse in policy-making. Although the UK government of the time also attempted to portray itself as 'green', this discourse was absent in the construction of its scrappage scheme. Conversely in Germany, a stronger car industry secured an earlier and more generous scrappage scheme, but one that for nationally specific reasons was framed in environmental terms. The countries demonstrate national differences in terms of the strength of environmental discourses, and the strength of domestic motor industries. These mobility regime differences have led to 'scrappage' being framed and implemented differently.

\section{Conclusion}

The story of how the hobbled cars and $\mathrm{CO}_{2}$ legislation gave way to the Year of Scrappage demonstrates the limited impact climate change discourse has had upon policy frames. While 'business as usual' had been agreed by policy-makers to be unsustainable, when it appeared under threat many rushed to call for its return. Invoking 'economic necessity' put environmental advocates onto the defensive and blocked the alternative possibility of encouraging a shift away from the car while mitigating negative social consequences of this shift. In other policy areas too, such as housing (where UK environmental standards have recently been weakened) apparent enthusiasm for 'the environment' has waned as an 'age of austerity' casts environmental protection as unaffordable luxury.

In Germany and the UK, recession talk was used to reframe transport policy around nationally organised support for car industries. However, the policy frames differed, shaped by differently constituted mobility regimes. In the UK, scrappage was initially delayed by the then Labour government's reluctance to be seen to subsidise 'old' manufacturing industry. In Germany the 'national interest' - constructed there as distinctively important for policy - was swiftly framed as securing the competitive position of its car industry. This overruled the international or global interest in sustainable futures yet was framed to construct scrappage as supporting such futures; as the environmental bonus. This is in line with a strong consensus within German society that developed countries should take a greater burden and carry greater responsibility for tackling climate change than less developed countries (Weidner 2005) - hence the need to present and perceive even apparently unpromising policies as exactly doing this. 
In the UK, the presentation of scrappage as purely economic demonstrated a profound failure to embed environmental criteria in transport policy-making The German picture is subtly different, indicated by the description of the scrappage scheme there as an environmental bonus. There the recession was still seen as offering a potential opportunity for the car industry to benefit from investing in 'clean technology'. This could be linked to the institutional 'greening" of German political discourse, and the history of a 'European social model' stressing 'win-win' solutions (i.e. in this case, a sustainable capitalism), weaker in the UK. In Germany, policy-makers' perceived continuing need to use 'environmental' discourse offers a potential opening for change, albeit shaped by the limits of 'ecological modernisation' discourse.

Despite the limitations and tensions inherent in dominant environmental discourses, the environmental framing of transport policies is potentially important in creating opportunities for more radical challenges. Within Germany, the politics of local pollution has helped to keep the door open for environmental policy frames. Within the UK, movements attempting to relocalise environmental issues may play a similar role. Yet in both countries debates around cars and $\mathrm{CO}_{2}$ are primarily conducted on behalf of 'the economy' or 'the environment' with issues around quality of life sidelined by a technological approach to climate change. Given the strong public interest in quality of life issues, strengthening this social dimension could contribute to maintaining an environmental framing in transport policy discourse.

At the beginning of this paper we suggested that scrappage provides an insight into broader problems related to transport policy development and how different national policy contexts continue to shape how this tension is framed and used to make policy. There are other substantial transport policy differences within a European context (for example, the positioning of cycling or the framing of public transport) that could be analysed using a similar approach. The European level entails its own cultural, political and economic interest constellations and particularities and further research would help to identify these. Combined with a clearer understanding of national mobility regimes this could help identify paths towards more sustainable transport futures. 


\section{Bibliography}

Aldred, R., 2010. "On the outside": constructing cycling citizenship. Social \& Cultural Geography 11(1), 35-52.

BBC, 2009. Carmakers urge scrappage renewal. http://news.bbc.co.uk/1/hi/8258643.stm (accessed 29 October 2009).

Brand, U., 2007. Die Internationalisierung des Staates als Rekonstitution von Hegemonie. Zur staatstheoretischen Erweiterung Gramscis in S. Buckel and A. FischerLescano, Andreas (eds). Hegemonie gepanzert mit Zwang. Zivilgesellschaft und Politik im Staatsverständnis Antonio Gramscis. Baden Baden: Nomos.

Bulkeley, H., 2005. Reconfiguring environmental governance: Towards a politics of scales and networks, Political Geography 24, 875-902

Bunce, S. and Desfor, G., 2007. Introduction to Political ecologies of urban waterfront transformations. Cities 24(4), 251-258.

Burningham, K. and Thrush, D., 2004. Pollution concerns in context: a comparison of local perceptions of the risks associated with living close to a road and a chemical factory. Journal of Risk Research 7(2), 213-232.

Church, R.A., 1995. The Rise and Decline of the British Motor Industry. Cambridge: Cambridge University Press.

Clark, A., 2009. Industry crisis sees US car dealerships cut loose and left with nothing to sell. The Guardian. 15 May 2009.

Daviter, F., 2007. Policy Framing in the European Union. Journal of European Public Policy 14(4), 654-666.

Della Porta, D. and Diani, M., 1999. Social Movements: an Introduction. Oxford: Blackwell.

Dennis, K. and Urry, J., 2009. After the Car. Cambridge: Polity Press.

Department for Environment, Food, and Rural Affairs, 2001. Survey of Public Attitudes to Quality of Life and the Environment.

http://www.defra.gov.uk/environment/statistics/pubatt/download/survey2001.pdf (accessed $28^{\text {th }}$ August 2009).

Department for Transport, 2009. Factsheets: UK Transport and Climate Change data. http://www.dft.gov.uk/pgr/statistics/datatablespublications/energyenvironment/climatecha ngefactsheets.pdf (accessed 29 October 2009).

Deutscher Bundestag, 1999. Drucksache 14/1082.

http://dip21.bundestag.de/dip21/btd/14/010/1401082.pdf (accessed 29 October 2009).

Deutschlandradio, 2009. Interview: Arbeitsexperte: Opel-Krise hat kaum Einfluss auf Region. http://www.dradio.de/dlf/sendungen/interview_dlf/313660/ (accessed 29

October 2009). 
Dudley, G., 1999. British Steel and Government since Privatization: Policy 'Framing' and the Transformation of Policy Networks. Public Administration 77(1), 51-71.

European Commission, 2007. Attitudes on issues related to EU Transport Policy: Analytical report (Eurobarometer 206b). http://ec.europa.eu/public opinion/flash/fl 206b en.pdf (accessed 29 October 2009).

Fletcher, A. L., 2009. Clearing the air: the contribution of frame analysis to understanding climate policy in the United States. Environmental Politics 18(5), 800 816.

Focus, 2009. Abrwrackpraemie schlaegt kriegsaehnliche Zustaende. http://www.focus.de/kultur/medien/wort-des-jahres-Abwrackprämie -schlaegtkriegsaehnliche-zustaende_aid_46431 (accessed 5 January 2010).

Giorgi, L. and Schmidt, M., 2002. European Transport Policy - a historical and forward looking perspective, German Policy Studies 2(4) (online).

Global Times, 2010. http://autos.globaltimes.cn/world/2010-02/502916.html (accessed 10 November 2010).

Golbuff, L. and Aldred, R. 2011. Cycling Policy in the UK: a historical and thematic overview. London: University of East London.

Gribben, R. and Dunkley, J., 2009. Angry Mini workers hurl fruit at union leaders after job cuts, Daily Telegraph, 15 February 2009.

Hajer, M., 1995. The politics of environmental discourse. Oxford: OUP.

Hall, D., 2010. Transport geography and new European realities: a critique. Journal of Transport Geography 18, 1-13.

Hammond, P., 2010. Government announces plans for next phase of high speed rail, speech available at

http://www.conservatives.com/News/Speeches/2010/10/Philip Hammond Government announces plans for next phase of high speed rail.aspx (accessed 5 November 2010).

Healey, P., 1999. Sites, Jobs and Portfolios. Urban Studies 36(1), 27-42.

IHS Global Insight, 2010. Assessment of the Effectiveness of Scrapping Schemes for Vehicles: Economic, Environmental, and Safety Impacts, http://ec.europa.eu/enterprise/sectors/automotive/files/projects/report scrapping schem es en.pdf (accessed 24 April 2011)

Jordan, A. (ed.), 2002. Environmental policy in the European Union: actors, institutions and processes. London: Earthscan.

Kagawa, S., Nansai, K., Kondo, Y., Hubacek, K., Suh, S., Minx, J., Kudoh, Y., Tasaki, T. and Nakamura, S. Role of Motor Vehicle Lifetime Extension in Climate Change Policy Environmental Science and Technology, 45 (4), 1184-1191

Kasemir, B. et al., 2000. Citizens' perspectives on climate change and energy use. Global Environmental Change 10, 169-184. 
Knill, C. and Lenschow, A., 1998. Coping with Europe: The Impact of British and German Administrations on the Implementation of EU Environmental Policy. Journal of European Public Policy 5, 595-614.

Lanning, P., 2009. Scrappage Now: We call on Government to pay for your bangers. The Sun 18 March 2009. Motors page 1.

Lowe, P. and Ward, S., 1998. Britain in Europe. Themes and issues in national environmental policy in P. Lowe and S. Ward (eds). British Environmental Policy and Europe. Politics and Policy in transition. Routledge: London and New York.

Mair, P., 1997. Party System Change: Approaches and Interpretations. Oxford: Clarendon Press.

Meyer, T., Schicha, C. and Brosda, C., 2002. Diskurs-Inszenierungen. Zur Struktur politischer Vermittlungsprozesse am Beispiel der "Ökologischen Steuerreform". Opladen: Westdeutscher Verlag.

Mol, A., 2001. Globalization and Environmental Reform: The Ecological Modernization of the Global Economy. Cambridge, MA: MIT Press.

Monbiot, G. 2009. This scam is nothing but a handout for motor companies, resprayed green. The Guardian Tuesday 10 March, http://www.guardian.co.uk/commentisfree/2009/mar/10/car-scrappage-payments (accessed 24 April 2011)

Motor Trade Index, 2010. European Car Markets continue to be buoyed by Scrappage Incentives, http://www.motor-trade-insider.com/index.php/2010/02/european-carmarkets-continue-to-be-buoyed-by-scrappage-incentives/ (accessed 7 February 2010).

Mulugetta, Y., Jackson, T. and van der Horst, D. 2010. Editorial: Carbon reduction at community scale, Energy Policy 38: 7541-7545

NAIGT (New Automotive Growth and Innovation Team), 2009. An Independent Report on the Future of the Automotive Industry in the UK, http://www.berr.gov.uk/files/file51139.pdf (accessed 29 October 2009).

Neues Fahren Website (http://www.neues-fahren.de/neues-fahren/default.htm (accessed 12 February 2010)

Nunnenkamp, P., 1998. Die deutsche Automobilindustrie im Prozess der Globalisierung, Die Weltwirtschaft, 3/1998: 294-315.

Nunnenkamp, P., 2008. Der Automobilstandort Deutschland unter Wettbewerbsdruck, Institut für Weltwirtschaft: Kiel.

NY Times, 2009.

http://www.nytimes.com/2009/08/07/business/07clunker.html? $r=2 \& h p=\& a d x n n \mid=1 \& a d x$ nnlx=1289377880-m/53vnpenLshZX+XVuycRA (accessed 10 November 2010)^.

NY Times, 2009a.

http://www.nytimes.com/2009/08/08/world/europe/08germany.html?_r=1\&scp=1\&sq=ger many\%20clunkers\&st=cse (accessed 29 October 2009). 
Pries, L., 2005. Rennaissance oder Agonie der deutschen und europaeischen Automobilindustrie http://www.ruhr-uni-bochum.de/soaps/download/publ2005_renaissance_oder_agonie.pdf (accessed 29 October 2009).

Ruddick, G. and Sibun, J., 2009. Car industry crisis deepens as sales fall further. The Telegraph, 4 April 2009.

Russland Aktuell, 2009. http://www.aktuell.ru/russland/wirtschaft/Abwrackprämie fuer altautos 2010 auch in russland 1997.html (accessed 10 November 2010).

Schattschneider, E.E., 1960. The Semisovereign People. A Realist View of Democracy in America, Florence US: Wadsworth Publishing.

Schön, D.A. and Rein, M., 1994. Frame reflection: toward the resolution of intractable policy controversies. New York: Basic Books.

Slocum, R., 2004. Consumer citizens and the Cities for Climate Protection Campaign. Environment and Planning A 36, 763-782.

Slocum, R., 2004a. Polar bears and energy-efficient lightbulbs: strategies to bring climate change home. Environment and Planning D 22, 413-438.

Snow, D., Rochford, E., Worden, S. and Benford, R., 1986. Frame Alignment Processes, Micromobilisation, and Movement Participation. American Sociological Review 51(4), 464-481.

Spiegel, der, 2009. http://www.spiegel.de/wirtschaft/0,1518,636193,00.html (accessed 10 November 2010).

Spiegel, der, 2009a. http://www.spiegel.de/wirtschaft/0,1518,643344,00.html (accessed 29 October 2009).

Stern, 2009. 'Abwrackprämie schlaegt Schweinegrippe' http://www.stern.de/kultur/buecher/wort-des-jahres-Abwrackprämie -schlaegtschweinegrippe-1530349.html (accessed 5 January 2010).

Stead, D., 2007. Transport energy efficiency in Europe: Temporal and geographical trends and prospects. Journal of Transport Geography 15(5), 343-353.

Tarrow, S., 1994. Power in Movement. Social Movements, Collective Action and Politics. New York and Cambridge: Cambridge University Press.

Transport and Environment, 2009. Scrappage payouts questionable on economic grounds. Available from http://www.transportenvironment.org/News/2009/6/Scrappagepayouts-questionable-on-economic-grounds/ (accessed $5^{\text {th }}$ November 2010).

Transport and Environment, 2009a. Bike 'scrappage' bonus offered in Germany. Available from http://www.transportenvironment.org/News/2009/5/Bike-scrappagebonus-offered-in-Germany/ (accessed $17^{\text {th }}$ November 2010).

Urry, J., 2010. Sociology Facing Climate Change. Sociological Research Online 15(3), 1, http://www.socresonline.org.uk/15/3/1.html. 
Walker, G., 2009. Globalizing Environmental Justice: The Geography and Politics of Frame Contextualization and Evolution. Global Social Policy 9(3), 355-382.

Walton, W. and Shaw, J., 2003. Applying the new appraisal approach to transport policy at the local level in the UK. Journal of Transport Geography 11(1), 1-12.

Webster, B., 2009. Road traffic falls for the first time in 30 years. The Times, 6 February 2009.

Weidner, H., 2005. Global Equity versus Public Interests? The Case of Climate Change Policy in Germany, Social Science Research Centre Berlin, Discussion Paper, SP IV 2004-102. 


\section{Acknowledgements}

This research was supported by a Promising Researcher grant from the University of East London. In addition to key stakeholders who kindly agreed to be interviewed, we would like to thank the participants in our LSE workshop "Decarbonising the Car" and the RGS-IBG session on 'Alternative Transport Futures' where this material was discussed.

Finally we would like to thank the anonymous peer reviewers and the editors who provided invaluable assistance in finalising this article for publication. 